\title{
PEMENUHAN KEWAJIBAN (PPh) PASAL 23 ATAS JASA FREIGHT FORWARDING OLEH PT. JASA PRIMA LOGISTIK PADA BULOG DI BAWAH ANAK PERUSAHAAN PERUM BULOG DIVRE NTB
}

\author{
Muhammad Alwi \\ Fakultas Ekonomi dan Bisnis Universitas Mataram \\ Muhnurrahmah303@gmail.com \\ M. Ricko Hidayat \\ Fakultas Ekonomi dan Bisnis Universitas Mataram \\ rikohidayat9960@gmail.com
}

\begin{abstract}
ABSTRAK
Pajak adalah iuran wajib rakyat kepada negara yang bersifat memaksa dan tidak mendapat balas jasa secara langsung, dan digunakan untuk membiayai pengeluaran negara. Salah satu jenis pajak yang dapat memberikan andil yang cukup besar adalah Pajak Penghasilan Pasal 23 atas Jasa Freight forwarding serta untuk membandingkan teori menurut Undang-Undang No 36 Tahun 2008 dengan peraktik yang diterapkan pada Perum BULOG Divre NTB khususnya tentang Penghitungan, Pemotongan, Penyetoran, serta Pelaporan Pajak Penghasilan Pasal 23.

Pajak Penghasilan Pasal 23 atas Jasa Freight Forwarding dipotong oleh Bagian Keuangan Perum BULOG Divre NTB selaku pihak ketiga antara pemberi penghasilaan dan penerima penghasilan, dilakukan pada saat penghasilan dibayarkan atau pada saat jatuh tempo pembayaran. Selanjutnya Bagian Keuangan Perum BULOG Divre NTB melakukan penyetoran pajak dengan menggunakan aplikasi e-Billing dan memebayar pajak terutang di Kantor POS atau Bank Persepsi, serta melakukan pelapoan melalui situs Djp Online dengan E-form.

Berdasarkan pembahasan penelitian ini, penulis dapat menarik beberapa kesimpulan yang berkaitan dengan penghitungan, pemotongan, penyetoran, dan pelaporan PPh Pasal 23 sebagai berikut: Perhitungan besaran PPh Pasal 23 atas jasa Fright Forwarding pada BULOG sudah sesuai dengan tarif yang telah di ataur pada pasal 23 ayat (1) Undang-Undang Nomor.36 Tahun 2008, Pelaksanaan Pemotonga PPh Pasal 23 atas jasa Freight Forwar pada Perum BULOG sudah sesuai Peraturan Mentri Keuangan Nomor 244/PMK.03/2008 sebagaimana yang telah diubah dalam Peraturan Mentri Keuangan 141/PMK.03/2015., Prosedur penyetoran PPh Pasal 23 atas Jasa Freight Forwarding pada Perum BULOG sudah sesuai dengan Peraturan Mentri Keuangan Republik Indonesia Nomor 242/PMK.03/2014 tentang Tata Cara Pembayaran dan Penyetoran Pajak, Prosedur Pelaporan PPh Pasal 23 atas Jasa Freight Forwarding pada Perum BULOG sudah sesuai dengan aturan yang ada, dan melaporkannya melalui situs DJP Online dengan E-Form.

Setelah dilakukannya perbandingan anatara Undang-Undang dan Peraturan Mentri Keuangan tentang Penghitungan, Pemotongan, Penyetoran serta Pelaporan PPh Pasal 23 atas Jasa Freight Forwarding pada Perum BULOG divre NTB tidak ditemukan perbedaan pelaksanaan tentang Penghitungan, Pemotongan, Penyetoran serta Pelaporan PPh Pasal 23 atau sudah sesuai dengan Undang-Undang serta Peraturan Mentri Keuangan, akan tetapi lebih baiknya Perum BULOG tetap melakukan kegiatan ini secaro konsisten dan di tingkatkan agar tercapainya kelancaran Penyetoran serta pelaporan PPh Pasal 23 sebagai motivasi bagi Wajib Pajak.

Kata kunci: Kewajiban PPh, Freight Forwarding
\end{abstract}

\section{PENDAHULUAN}

Suatu bangsa yang besar dapat dilihat dari cara mengelola penerimaan negara dalam membiayai pembangunan nasional seperti pembangunan yang di terima oleh negara di peroleh dari sumber, yaitu: penerimaan negara dari sektor pajak dan penerimaan negara dari sektor bukan pajak, yaitu sektor migas dan non-migas. 
Saat ini dalam pemungutan pajak di Indonesia menganut system pemungutan pajak Self Assessment, Official Assesment dan Withholding Tax System. Dalam hal ini yang menggunakan Withholding Tax System adalah (PPh pasal 23), yaitu pajak penghasilan yang di kenakan atas penghasilan Wajib Pajak Dalam Negri atau Bentuk Usaha Tetap yang menerima atau memperoleh penghasilan yang berasal dari modal, penyerahan jasa, atau penyelenggara kegiatan selain yang telah di potong pajak sebagaimana dimaksud dalam PPh Pasal 23

Pajak penghasilan sudah beberapa kali mengalami perubahan undang-undang. Hal ini di maksudkan untuk meningkatkan fungsi dan peranan perpajakan dalam rangka mendukung suatu kebijakan pembangunan nasional, khususnya di bidang ekonomi, sebagaimana di maksud dalam Pasal 23 Ayat (1) Huruf c Angka 2 undang-undang Nomor 7 Tahun 1983 tentang Pajak Penghasilan yang telah di ubah terakhir dengan undangundang Nomor 36 Tahun 2008. Peraturan pajak penghasilan sudah di atur dalam UU pajak penghsilan Pasal 23 No. 36 Tahun 2008, dimana yang dapat memotong PPh pasal 23 adalah badaan pemerintaah, wajib pajak dalam negri, penyelenggara kegiatan , bentuk usaha tetap, perwakilan perusahaan luar negri lainnya, dan Wjib Pajak orang pribadi dalam negri tertentu yang di ajukan oleh Direktur Jendral Pajak. Dengan di terbitkannya UU No. 36 Tahun 2008 tentang ketentuaan umum dan tatacara perpajakan di harapkan wajib pajak menjadi lebih patuh dan diterbitkan segala bentuk kemudahan dalam peroses perpajakan.

Ketentuan mengenai hal lain sehubungan dengn jasa yang di kenaakan PPh 23 diataur dalam peraaturan Mentri Keuangan Nomor 22/PMK.03/2008 tentang Jenis Jasa Lain yang sebagaimana telah diubah PMK 141/PMK.03/2015 dan sudah mengalami beberapa tambahan dari yang sebelumnya. Salah satunya adalah jasa freight forwarding atau di kenal dengan istilah jasa pengurusan transportasi atau bertujuan untuk mempercepet proses transportasi sehingga barang dapat terkirim dengan waktu yang diinginkan dan kondisi baraang aman dan tidak rusak. Kegiatan jasa feright forwarding ini merupakan kegiatan usaha yang memberikan pelayanan melalui penerimaan barang, penyimpanan barang, sortasi barang, pengepakan barang, penanadaan barang, pengukuran barang, penimbangan barang, pengurusan penyelesaian dokumen, penerbitan dokumen angkutan, perhitungan transportasi luar negri. Biasanya system pembayaran bersifat reimbursement dimana reinvoicing membuat tagihan kepada konsumen yang rinciannya tergantung jenis jasa apa yang di berikan forwarder kepada konsumen. Tagihan yang di berikan forwarder ke konsumen, ada beberapa skema antara lain tagihan di mana biaya jasa dan biaya angkutan terpisah maka satu tagihan atas nama forwarder langsung (tagihan atas jasanya) saja dan tagihan lainnya atas nama perusahaan pelayaran (tagihan atas biaya pengangkutannya). Skema lainnya tagihan di mana biaya jasa dan biaya angkutan menhadi satu paket sehingga tagihan atas nama forwarder saja.

Jasa freight forwarding sangat dibutuhkan untuk keperluan pengangkutan pangan di BULOG dan sangat sering terjadi adanya transaksi. Selain peran BULOG untuk memenuhi kebutuhan pangan dengan menggunakan jasa freight forwarding. Dengan ini membuat nominal jasa freight forwarding dalam setahunnya cukup besar. Salah satu perusahaan yang melakukan jasa freight forwarding adalah PT. Jasa Perima Logistik adalah anak perusahaan dari Perum BULOG melakukan usaha di bidang Freight Forwarding, Wearehousing dan Project Shipment, jasa logistic dan angkutan serta usaha pendukung lainnya untuk menghasilkan barang dan jasa yang bermutu tinggi dan bedaya saing kuat, baik di dalam maupun di luar wilayah Indonesia untuk mendapatkan keuntungan guna meningkatkan nilai perseroan dengan tetap menerapkan prinsif-prinsif Perseroan Terbatas. 


\section{TUJUAN}

Adapun tujuan dari penulis untuk melaksanakan Penelitian ini adalah:

1. Untuk mengetahui Mekanisme Penghitungan, Pemotongan, Penyetoran serta Pelaporan (PPh) pasal 23 atas jasa freight forwarding pada PT. Jasa Prima Logistik pada Perusahaan Bulog Divre NTB.

2. Untuk membandingkan antara teori dan praktek Penghitungan, Pemotongan, Penyetoran serta Pelaporan (PPh) pasal 23 atas Jasa pada Perusahan Perum Bulog Divre NTB yang telah di pelajari di bangku kuliah.

\section{TELAAH LITERATUR DAN [PENGEMBANGAN HIPOTESIS}

\section{Pengertian Pajak}

Banyak definisi atau batasan pajak yang telah dikemukakan oleh para pakar, yang satu sama lain pada dasarnya memiliki tujuan yang sama yaitu merumuskan pengertian pajak sehingga mudah dipahami. Perbedaannya hanya terletak pada sudut pandang yang digunakan oleh masing-masing pihak pada saat merumuskan pengertian pajak menurut ketentuan umum dan tata cara perpajakan yang disebutkan pada pasal 1 angka 1 yang berbunyi sebagai berikut:

"Pajak adalah kontribusi wajib kepada Negara yang terutang oleh orang pribadi atau badan yang bersifat memaksa berdasarkan undang-undang, dengan tidak mendapatkan imbalan secara langsung dan digunakan untuk keperluan Negara bagi sebesar besarnya kemakmuran rakyat".

Berdasarkan UU KUP NOMOR 28 TAHUN 2007, pasal 1, ayat 1, pengertian Pajak adalah kontribusi wajib kepada negara yang terutang oleh orang pribadi atau badan yang bersifat memaksa berdasarkan undang-undang, dengan tidak mendapatkan imbalan secara langsung dan digunakan untuk keperluan negara bagi sebesar-besarnya kemakmuran rakyat. Berdasarkan pengertian tersebut, maka pajak memiliki ciri-ciri sebagai berikut :

1. Pajak Merupakan Kontribusi Wajib Warga Negara

Artinya setiap orang memiliki kewajiban untuk membayar pajak.Namun hal tersebut hanya berlaku untuk warga negara yang sudah memenuhi syarat subjektif dan syarat objektif.Yaitu warga negara yang memiliki Penghasilan Tidak Kena Pajak (PTKP) lebih dari Rp 2.050.000 perbulan. Jika Anda adalah karyawan/pegawai, baik karyawan swasta maupun pegawai pemerintah, dengan total penghasilan lebih dari Rp 2 juta, maka wajib membayar pajak. Jika Anda adalah wirausaha, maka setiap penghasilan akan dikenakan pajak sebesar $1 \%$ dari total penghasilan kotor/bruto (berdasarkan PP 46 tahun 2013).

2. Pajak Bersifat Memaksa Untuk Setiap Warga Negara

Jika seseorang sudah memenuhi syarat subjektif dan syarat objektif, maka wajib untuk membayar pajak.Dalam undang-undang pajak sudah dijelaskan, jika seseorang dengan sengaja tidak membayar pajak yang seharusnya dibayarkan, maka ada ancaman sanksi administratif maupun hukuman secara pidana.

3. Warga Negara Tidak Mendapat Imbalan Langsung

Pajak berbeda dengan retribusi. Contoh retribusi: ketika mendapat manfaat parkir, maka harus membayar sejumlah uang, yaitu retribusi parkir, namun pajak tidak seperti itu. Pajak merupakan salah satu sarana pemerataan pendapatan warga negara. Jadi ketika membayar pajak dalam jumlah tertentu, Anda tidak langsung menerima manfaat pajak yang dibayar, yang akan Anda dapatkan berupa perbaikan jalan raya di daerah Anda, fasilitas kesehatan gratis bagi keluarga, beasiswa pendidikan bagi anak Anda, dan lain-lainnya.

4. Berdasarkan Undang-undang 
Artinya pajak diatur dalam undang-undang negara.Ada beberapa undangundang yang mengatur tentang Tata Cara pengitungan, pemungutan, dan penyetoran pajak yaitu Undang-Undang No 30 Tahun 2014. Beberapa ahli memberikan batasan tentang pajak.Kutipan bebrapa pengertian pajak yang dikemukakan para ahli, adalah sebagai berikut :

a. Menurut Andriani

"Pajak adalah iuran kepada negara (yang dapat dipaksakan ) yang terutang oleh yang wajib membayarnya menurut peraturan-peraturan, dengan tidak mendapat prestasi kembali yang langsung dapat ditunjuk, dan yang gunanya adalah untuk membiayai pengeluaran-pengeluaran umum berhubung dengan tugas negara menyelenggarakan pemerintahan" (Waluyo, 2007:1).

b. Menurut Rochmat Soemitro

"Pajak adalah iuran rakyat kepada kas negara berdasarkan Undang-Undang (yang dapat dipaksakan) dengan tidak mendapat jasa timbal balik (kontraprestasi) yang langsung dapat ditunjukkan, dan yang digunakan untuk membayar pengeluaran umum" (Resmi, 2011:1).

Dari definisi tersebut dapat diketahui ciri-ciri yang melekat pada pengertian pajak, yaitu:

1. Pajak dipungut berdasarkan Undang-Undang serta aturan pelaksanaannya.

2. Dalam pembayaran pajak tidak dapat ditunjukkan adanya kontraprestasi secara individual oleh pemerintah.

3. Pajak dipungut oleh Negara (Pemerintah Pusat maupun Pemerintah Daerah).

4. Pajak diperuntukkan membiayai pengeluaran pemerintah apabila pemasukannya masih surplus, dipergunakan untuk publik investment.

c. Menurut Smeeths

Pajak merupakan sebuah prestasi yang dicapai oleh pemerintah yang terhutang dengan melalui berbagai norma serta dapat untuk dipaksakan tanpa adanya kontrak prestasi dari masing-masing individual, maksudnya adalah untuk membiayai pengeluaran pemerintah.

\section{Fungsi Pajak}

Menurut Mardiasmo pajak mempunyai 2 fungsi yaitu:

1. Fungsi Anggaran (Budgetair)

Pajak berfungsi sebagai salah satu sumber dana bagi pemerintah untuk membiayai pengeluaran-pengeluarannya.

2. Fungsi Mengatur (Regulerend)

Pajak berfungsi sebagai alat untuk mengatur atau melaksanakan kebijaksanaan pemerintah dalam bidang sosial dan ekonomi

\section{Pengelolaan Pajak}

1. Menurut golongan

a. Pajak langsung

Pajak langsung adalah pajak yang pembebanannya tidak dapat dilimpahkan kepada pihak lain, tetapi harus menjadi beban langsung wajib pajak yang bersangkutan.

Contoh: Pajak Penghasilan (PPh)

b. Pajak tidak langsung

Pajak tidak langsung adalah pajak yang pembebanannya dapat dilimpahkan ke pihak lain.

Contoh: Pajak Pertambahan Nilai (PPN)

2. Menurut sifatnya

a. Pajak subjektif 
Pajak subjektif adalah pajak yang barpangkal atau didasarkan pada subjeknya yang selanjutnya di carisyarat objektifnya, dalam arti memperhatikan keadaan wajib pajak.

Contoh: Pajak Penghasilan (PPh)

b. Pajak objektif

Pajak objektif adalah pajak yang berpangkal atau berdasarkan pada objeknya, tampa memperhatikan keadaan wajib pajak.

Contoh: Pajak Pertambahan Nilai (PPN) dan Pajak Pertambahan Nilai atas Barang Mewah (PPnBM).

3. Menurut pemungut dan pengelolaannya

a. Pajak pusat

Pajak pusat adalah pajak yang dipungut oleh pemerintah pusat dan digunakan untuk membiayai rumah tangga Negara.

Contoh:

1. PPh

2. $\mathrm{PPnBM}$

3. $\mathrm{PBB}$

4. Bea materai

5. Bea Lelang

b. Pajak daerah

Pajak daerah adalah pajak yang dipungut oleh pemerintah daerah dan digunakan untuk membiayai rumah tangga Negara.

Contoh:

1. Macam-macam Pajak provinsi:
a. Pajak kendaraan bermotor
b. Bea balik nama kendaraan bermotor
c. Pajak bahan bakar kendaraan bermotor
d. Pajak air permukaan, dan pajak rokok

2. Macam-macam pajak kabupaten/kota:
a. Pajak hotel
b. Pajak restoran
c. Pajak hiburan
d. Pajak reklame
e. Pajak penerangan jalan
f. Pajak mineral bukan logamdan batuan/pajak atas pengolahan Bahan Galian Golongan C.
g. Pajak parker
h. Pajak air tanah
i. Pajak sarang burung wallet
j. Pajak bumi dan bangunan perdesaan dan perkotaan
k. Bea perolehan hak atas tanah dan bangunan

\section{System Pemungutan Pajak}

Ada 3 system pemungutan pajak yaitu :

\section{Official Assesment System}

System ini merupakan wewenang kepada Negara untuk melakukan perhitungan pajak yang terhutang oleh rakyat. Dalam system ini rakyat bersifat pasif, besarnya beban pajak yang harus di bayar oleh rakyat menunggu surat ketetapan pajak yang diterbitkan oleh Negara.

2. Self Assessment System 
Self Assessment System Adalah suatu sistem pemungutan pajak yang memberi wewenang kepada Wajib Pajak untuk menentukan sendiri besarnya pajak yang terutang.ciri-cirinya :

a. Wewenang untuk menentukan besarnya pajak terutang ada pada Wajib Pajak sendiri

b. Wajib Pajak aktif, mulai dari menghitung, menyetor dan melaporkan sendiri pajak yang terutang, dan

c. Fiskus tidak ikut campur dan hanya mengawasi.

3. With Holding System

With Holding System adalah Suatu sistem pemungutan pajak yang memberi wewenang kepada pihak ketiga (bukan fiskus dan bukan Wajib Pajak yang bersangkutan) untuk menentukan besarnya pajak yang terutang oleh Wajib Pajak.

\section{Asas Pemungutan Pajak}

Untuk mencapai tujuan pemungutan pajak perlu dipegang teguh asas-asas pemungutan dalam memilih alternatif pemungutannya. Dengan demikian, terdapat keserasian pemungutan pajak dengan tujuannya. Terdapat tiga azas yang digunakan untuk memungut pajak dalam pajak penghasilan menurut Siti Kurnia Rahayu (2010) yaitu :

\section{Azas Domisili}

Maksudnya bahwa apabila pemerintah hendak melaksanakan pemungutan pajak berdasarkan azas ini, maka yang menjadi dasar pemungutannya adalah tempat tinggal si wajib pajak (domisili) dengan tidak memandang di mana pendapatan ini berasal, apakah dari dalam atau luar negeri. Selain itu kebangsaannya tidak mempengaruhi dalam hal pemungutan pajak. Jadi apabila seseorang asing tinggal di negara yang menganut azas domisili, ia pun akan terkena pajak dari negara tersebut.

2. Azas Kebangsaan

Pajak yang berdasarkan azas kebangsaan ini adalah pajak yang dikenakan suatu negara pada orang-orang yang mempunyai kebangsaan dari negara tersebut, dengan tidak memperdulikan di mana wajib pajak itu bertempat tinggal (yang dilihat adalah kebangsaan wajib pajak).

3. Azas Sumber

Menurut azas sumber cara pemungutan pajaknya adalah dengan melihat objek pajak tersebut bersumber dari mana, jadi apabila di suatu negara terdapat sumber-sumber penghasilan, maka negara tersebutlah yang berhak memungut pajaknya dengan tidak menghiraukan tempat di mana wajib pajak itu berada.

Ciri-cirinya: Wewenang menentukan besarnya pajak yang terutang ada pada pihak ketiga, pihak selain fiskus dan Wajib Pajak.

\section{Pajak Penghasilan Pasal 23}

Pajak penghasilan (PPh) pasal 23 adalah pajak yang di potong atas penghasilan yang beasal dari modal, penyerahan jasa, atau hadian dan penghargaan, selain setelah di potong PPh pasal 21. Umumnua penghasilan jenis ini terjadi saat adanya transaksi antara dua pihak. Pihaak yang menerima penghasilan atau penjual atau pemberi jasa akan di kenakaan PPh Pasal 23. Pihak pemberi penghasilan atau pemberi, penerima jasa akan memeotong dan melaporkan PPh pasal 23 tersebut kepada kantor pajak.

Menurut Madiasmo (2011: 235), ketentuan dalam Undang-Undang Pajak Penghasilan Pasal 23 mengatur pemotongan pajak atas penghasilan yang diterima atau diperoleh wajib pajak dalam negeri dan bentuk usaha tetap yang berasal dari modal, penyerahan jasa, atau penyelenggaraan kegiatan selain yang telah dipotong PPh Pasal 21, yang dibayarkan, disediakan untuk dibayarkan, atau telah jatuh tempo pembayarannya oleh badan pemerintah, subjek pajak badan dalam negeri, 
penyelenggara kegiatan, bentuk usaha tetap, atau perwakilan perusahaan luar negeri lainnya. Supramono dan Damayanti (2010:85) menegaskan bahwa PPh Pasal 23 adalah pajak yang dipotong atas penghasilan yang diterima atau diperoleh wajib pajak dalam negeri (orang pribadi atau badan), serta bentuk usaha tetap dengan nama dan dalam bentuk apa pun yang berasal dari modal, penyerahan jasa, atau penyelenggaraan kegiatan selain yang telah dipotong PPh Pasal 21, meliputi dividen, royalti, hadiah dan penghargaan, sewa, penghasilan sehubungan dengan penggunaan harta, dan imbalan jasa tertentu.

Pasal 23 Ayat (1) Huruf c Angka 2 Undang-Undang Nomor 7 tahun 1983 tentang Pajak Penghasilan sebagaimana telah beberapa kali diubah terakhir dengan UndangUndang Nomor 36 Tahun 2008 mengatur bahwa penghasilan berupa imbalan sehubungan dengan jasa teknik, jasa manajemen, jasa konstruksi, jasa konsultan, dan jasa lain selain jasa yang telah dipotong PPh sebagaimana dimaksud dalam Pasal 21, dikenakan tarif sebesar dua persen dari penghasilan bruto. Dalam hal wajib pajak yang menerima atau memperoleh penghasilan sebagaimana dimaksud pada Ayat (1) tidak memiliki Nomor Pokok Wajib Pajak, besarnya tarif pemotongan adalah lebih tinggi seratus persen dari pada tarif sebagaimana dimaksud pada Ayat (1).

\section{Pemotongan dan Penerimaan Penghasilan yang Dipotong PPh Pasal 23}

1. Pemotongan PPh pasal 23 sebagaimana di maksud dalam Undang-Undang-Undang Pasaal 23 ayat (1) No. 36 Tahyn 2008:

a. Badan pemerintahan

b. Subjek Pajak badan dalam negri.

c. Penyelenggaran kegiatan

d. Bentuk usahaa tetap (BUT)

e. Perwaakilan perusahaan luar negri lainnya

f. Waajib pajak orang pribadi dalam negri tertentu, yang ditunjuk oleh Direktur Jendral Pajak.

2. Penerimaan penghasilan yang di potong PPh pasal 23:
a. Wjib Pajak dalam negri

b. Badan Usaha Tetap

\section{Tarif dan Objek PPh Pasal 23}

berikut:

Pasal 23 ayat (1) Undang-Undang No. 36 Tahun 2008 menetapkan tariff sebagai

1. $15 \%$ dari jumlah bruto atas:

a. dividen kecuali pembagian dividen kepada orang pribadi di kenakan final, bunga, dan royalty

b. hadiah dan penghargaan selain yang telah di potong PPh pasal 21 .

2. $2 \%$ dari jumlah bruto atas sewa dan penghasilan lain sehubungan dengan penggunaan harta kecuali sewa tanah dan/atau bangunan.

3. $2 \%$ dari jumlah bruto atas imbalan jasa teknik, jasa manajemen, jasa kontruksi dan jasa konsultan

4. $2 \%$ dari jumlah bruto atas imbalan jasa, lainnya, yaitu:

5. Tidak ber-NPWP di potong $100 \%$ lebih tinggi dari tarif PPh Pasal 23.

6. Yang di maksud dengan jumlah bruto adalah seluruh jumlah penghasilan yang dibayarkan, disediakan untuk dibayarkan, subjek pajak dalam negeri, penyelenggaraan kegiatan, bentuk usaha tetap, atau perwakilan perusahaan luar negeri lainnya kepada wajib pajak dalam negeri atau bentuk usaha tetap, tidak termasuk:

a. Pembayaran gaji, upah, honorarium, tunjangan dan pembayaran lain sebagai imbalan sehubungan dengan pekerjaan yang di bayarkan oleh WP penyedia tenaga 
kerja kepada tenaga kerja yang melakukan pekerjaan, berdasarkan kontrak dengan pengguna jasa.

b. Pembayaran atas jasa pengadaan dan pembayaran barang atau material (dibuktikan dengan faktur pembelian)

c. Pembayaran kepada pihak kedua (sebagai perantara) untuk selanjutnya di bayarkan kepada pihak ketiga (dibuktikan dengan faktur tagihan pihak ketiga disertai dengan perjanjian tertulis).

d. Pembayaran penggantian biaya (reimbursement) yaitu penggantian pembayaran sebesar jumlah yang nyata-nyata telah di bayarkan oleh pihak kedua kepada pihak ketiga (dibuktikan dengan faktur tagihan atau bukti pembayaran yang telah dibayarkan kepada pihak ketiga).

Jumlah bruto tersebut tidak berlaku:

a. Atas penghasilan yang di bayarkan sehubungan dengan jasa catering.

b. Dalam hal penghasilan yang dibayarkan sehubungan dengan jasa, telah di kenakan pajak bersifat final.

\section{Penghitungan PPh Pasal 23 Terutang yang Dikecuali dari pemotongan}

Dikecualikan dari pemotongan PPh Pasal 23 ayat ( 4 ) Undang-Undang No 36 Tahun 2008 adalah :

1. Penghasilan yang dibayarkan atau terutang kepada bank.

2. Sewa yang dibayar atau terutang sehubungan dengan sewa guna usaha dengan hak opsi.

3. Deviden atau bagian laba yang di terima atau di peroleh perseroan terbatas sebagai wajib pajak dalam negeri, koprasi, BUMB/BUMD, dari penyertaan modal pada badan usaha yang didirikan dan bertempat kedudukan di Indonesia dengan syarat:

a. Dividen berasal dari cadangan laba yang ditahan.

b. Bagi perseroan terbatas, BUMN/BUMD, kepemilikan saham pada badan yang memberikan dividen paling rendah 25\% (dua puluh lima persen) dari jumlah modal yang di setor.

c. Bagian laba yang diterima atau di peroleh anggota dari perseroan komaditer yang modalnya tidak terbagi atas saham-saham persekutuan, perkumpulan, firma dan kongsi termasuk pemegang unit penyertaan kontrak investasi kolektif.

d. Sisa hasil usaha koprasi yang di bayarkan oleh koprasi kepada aanggotanya

e. Penghasilan yang di bayar atau terutang kepada badan usaha atau jasa keuangan yang berfungsi sebagai penyalur pinjaman atau pembiayaan.

\section{Pemotongan PPh Pasal 23 Saat Terutang}

1. Apabila anda membayarkan dividen kepada PT sebagai Wajib Pajak Dalam Negeri (WPDN), koperasi, BUMN, atau BUMD yang jumlah kepemilikan sahamnya dibawah $25 \%$ maka Pemotongan PPh Pasal 23 sebesar $15 \%$ saat dividen disediakan untuk dibayarkan dan membuat bukti potong PPh Pasal 23 melalui aplikasi e-bupot PPh pasal 23.

2. Apabila anda melakukan peminjaman dana dan membayarkan Bunga kepada pemilik dana, maka Pemotongan PPh Pasal 23 sebesar 15\% dari bruto nilai bunga dan membuat bukti potong PPh Pasal 23 melalui aplikasi e-bupot PPh pasal 23.

3. Apabila anda membayarkan royalti kepada pihak penerima royalti, maka Pemotongan PPh Pasal 23 sebesar 15\% dari jumlah bruto nilai royalti dan membuat bukti potong PPh Pasal 23 melalui aplikasi e-bupot PPh pasal 23.

4. Apabila anda menggunakan jasa dari WP badan, maka yang harus Anda lakukan adalah Meneliti apakah jasa yang digunakan itu adalah termasuk jenis jasa yang merupakan objek PPh Pasal 23 berdasarkan PMK-141/PMK.03/2015 dan Melakukan 
Pemotongan PPh Pasal 23 sebesar $2 \%$ dari jumlah bruto nilai jasa dan membuat bukti potong PPh Pasal 23 melalui aplikasi e-bupot PPh pasal 23.

5. Apabila anda menyewa harta selain tanah dan/atau bangunan, maka pemotongan PPh Pasal 23 sebesar $2 \%$ dari jumlah bruto nilai sewa dan membuat bukti potong PPh Pasal 23 melalui aplikasi e-bupot PPh pasal 23.

\section{Penyetoran PPh Pasal 23 Saat Terutang}

1. Berdasarkan ketentuan Pasal 2 Peraturan Menteri Keuangan Nomor 80/PMK.03/2010 tanggal 1 April 2010 yang merupakan perubahan atas Peraturan Menteri Keuangan Nomor 184/PMK.03/2007, PPh Pasal 23 yang dipotong oleh Pemotong PPh harus disetor paling lama tanggal 10 (sepuluh) bulan berikutnya setelah Masa Pajak berakhir.

2. Dalam hal tanggal jatuh tempo pembayaran atau penyetoran pajak bertepatan dengan hari libur termasuk hari Sabtu atau hari libur nasional, pembayaran atau penyetoran pajak dapat dilakukan pada hari kerja berikutnya. Dalam pengertian hari libur nasional termasuk hari yang diliburkan untuk penyelenggaraan Pemilihan Umum yang ditetapkan oleh Pemerintah dan cuti bersama secara nasional yang ditetapkan oleh Pemerintah.

3. Pembayaran dan penyetoran pajak harus dilakukan dengan menggunakan Surat Setoran Pajak (SSP) atau sarana administrasi lain yang disamakan dengan Surat Setoran Pajak. SSP ini berfungsi sebagai bukti pembayaran pajak apabila telah disahkan oleh pejabat kantor penerima pembayaran yang berwenang atau apabila telah mendapatkan validasi. SSP dianggap sah jika telah divalidasi dengan Nomor Transaksi Penerimaan Negara (NTPN). Adapun tempat pembayaran adalah Kantor Pos atau bank yang ditunjuk oleh Menteri Keuangan sebagai tempat pembayaran pajak

\section{Pelaporan PPh Pasal 23 Saat Terutang}

1. Pemotong PPh Pasal 23 wajib memberikan tanda bukti pemotongan PPh Pasal 23 kepada orang pribadi atau badan yang dipotong setiap melakukan pemotongan atau pemungutan. Bagi penerima penghasilan, bukti pemotongan PPh Pasal 23 ini adalah bukti pelunasan PPh terutang dalam tahun tersebut yang nantinya akan dikreditkan dalam SPT Tahunannya.

2. Apabila masa pajak telah berakhir, pemotong PPh Pasal 23 wajib melaporkan pemotongan yang telah dilakukan dalam masa pajak tersebut. Pelaporan ini dilakukan dengan menyampaikan SPT Masa PPh Pasal 23/26 ke Kantor Pelayanan Pajak tempat Wajib Pajak pemotong PPh Pasal 23 terdaftar.

3. Surat Pemberitahuan (SPT) Masa PPh Pasal $23 / 26$ harus disampaikan paling lama 20 (dua puluh) hari setelah Masa Pajak berakhir. Contoh, untuk pemotongan PPh Pasal 23 bulan Juli 2021, SPT Masa PPh Pasal 23 harus disampaikan paling lambat tanggal 20 Agustus 2021.

4. Dalam hal batas akhir pelaporan di atas bertepatan dengan hari libur termasuk hari Sabtu atau hari libur nasional, pelaporan dapat dilakukan pada hari kerja berikutnya. Pengertian hari libur nasional termasuk hari yang diliburkan untuk penyelenggaraan Pemilihan Umum yang ditetapkan oleh Pemerintah dan cuti bersama secara nasional yang ditetapkan oleh Pemerintah.

\section{HASIL PENELITIAN DAN PEMBAHASAN}

BULOG adalah perusahaan umum milik negara yang bergerak di bidang logistik pangan. Sebagai perusahaan yang tetap mengemban tugas publik dari pemerintah, 
BULOG tetap melakukan kegiatan menjaga Harga Dasar Pembelian (HDP) untuk gabah, stabilisasi harga khususnya harga pokok, menyalurkan beras untuk orang miskin (Raskin) dan pengelolaan stok pangan. Perum BULOG Divre NTB bertempat kedudukan di Jalan Jend.Ahmad Langko No.110, Mataram.

BULOG melakukan pengangkutan logisitik pangan menggunakan 2 jalur pengangkutan yaitu pengangkutan melalui darat dan laut. Bulog menggunakan jasa pengangkutan atau jasa freight forwarding dari anak perusahaan nya yaitu PT. Jasa Prima Logisitk. Bulog sebagai Badan Pemerintah (BUMN) yang telah ditunjuk Dirjen Pajak sebagai Wajib Potong PPh 23 untuk memotong penerima penghasilan yang termasuk objek penghasilan yang dikenakan PPh 23, dan Tarif Pajak Pasal 23 ayat (1) UndangUndang No. 36 Tahun 2008 adalah $2 \%$ dari jumlah bruto atas imbalan sehubungan dengan jasa teknik, jasa manajemen, jasa konstruksi, jasa konsultan, dan jasa lain selain jasa yang telah dipotong Pajak Penghasilan sebagaimana dimaksud dalam Pasal 21. Atas jasa lain yang dimaksud diatur dalam Peraturan Menteri Keuangan Nomor 141/PMK.03/2015 perubahan atas Peraturan Menteri Keuangan Nomor 244/PMK.03/2008, yaitu jasa freight forwarding.

Topik yang diambil dalam penelitian yang dilaksanaakan di Perum BULOG Divre NTB adalah Pemenuhan Kewajiban (PPh) Pasal 23 atas jasa Freight Forwarding adalah sebuah perusahaan yang bergerak dalam bidang keagenan yang mengurusi pengiriman dan penerimaan barang Export dan Import atau Nasional. Freight forwarding ini bisa dikatakan sebagai agent Shiping Agent Carrier. Menurut Peraturan Mentri Keuangan Nomor 244/PMK.03/2008 sebagaimana telah diubah dalam Peraturan Menteri Keuangan Nomor 141/PMK.03/2015 yang menjelaskan Jasa Freight forwarding seperti yang disebutkan dalam Pasal 1 ayat (6) adalah kegiatan usaha yang ditunjukan untuk mewakili kepentingan pemilik untuk mengurus semua atau sebagian kegiatan yang diperlakukan bagi terlaksananya pengiriman dan penerimaan barang melalui transportasi darat, laut, dan udara, yang dapat mencakup kegiatan penerimaan, penyimpanan, sortasi, pengepakan, penandaan, pengukuran, penimbangan, pengurusan penyelesaian dokumen, penerbitan dokumen angkut, perhitungan biaya angkut, klain asuransi atas pengiriman barang serta penyelesaian tagihan dan biaya-biaya lainnya, berkenaan pengiriman barang-barang tersebut sampai dengan diterimanya baarang oleh yang berhak menerimanya. PT. Jasa Perima Logistik, Perum BULOG Divre NTB sebagai wajib potong, memotong Pajak Penghasilan 23 pada wajib pajak dalam negri ( oarang pribadi atau badan), dalam hal ini PT. Jasa Prima Logistik adalah Wajib Pajak badan yang yang perupakan anak perusahaan sekaligus mitra bisnis Perum BULOG Divre NTB, Didalam Pembahasan disini akan menjelaskan pelaksanaan proses pengangkutan logistik Perum BULOG Divre NTB yang dilakukan Jasa Prima Logisitik, pengenaan Pajak Penghasilan Pasal 23 atas Pengangkutan Logisitikyang dilakukan PT. Jasa Prima Logisitik, Pemotongan, Penyetoran dan Pelaporan PPh 23, oleh Perum Bulog Divisi Regional Nusa Tenggara Barat.

\section{Proses Pengangkutan Logistik Ke Perum BULOG}

Perum BULOG Divre NTB melaksanakan kegiatan bisnis dengan beberapa kegiatan, antara lain pengelolaan komoditi Beras, Gula, Kedelai, Daging, Ikan dan Komoditi lainnya. Pengangkutan merupakan kegiatan transportasi dalam memindahkan barang dan penumpang dari satu tempat ke tempat lain atau dapat dikatakan sebagai kegiatan ekspedisi. Pengangkutan berfungsi untuk memindahkan barang atau orang dari suatu tempat ke tempat yang lain dengan maksud untuk meningkatkan daya guna dan nilai. Proses pemindahan barang tersebut dilakukan melalui darat, laut, udara dan perairan darat atau sungai dengan menggunakan berbagai jenis alat transportasi sesuai dengan kebutuhannya. Sebagai suatu kegiatan jasa dalam memindahkan barang atau pun penumpang dari suatu tempat ke tempat lain, pengangkutan berperan sekali dalam 
mewujudkan terciptanya pola distribusi nasional yang dinamis. Praktik penyelenggaraan suatu pengangkutan harus dapat memberikan nilai guna yang sebesar-besarnya dalam dunia perdagangan. Serta pelaksanaannya harus dilakukan secara adil dan merata kepada segenap lapisan masyarakat dan lebih mengutamakan kepentingan pelayanan umum bagi masyarakat. Menjalankan kegiatan bisnis logisitiknya dibidang pangan, Perum Bulog Divre NTB melakukan pengiriman logistik ke berbagai daerah di seluruh Indonesia secara merata guna mendukung untuk membangun ekonomi nasional khususnya dalam rangka pelaksanaan program pembangunan nasional di bidang pangan.

Perum Bulog Divre NTB menggunakan jasa freight forwarding untuk membantu kemudahan pendistribusian bahan pangan dan komiditi lainnya. Bahan pangan tersebut antara lain beras, gula, tepung, minyak goreng. Salah satu pengiriman yang dilakukan Perum BULOG adalah pengiriman Beras.

Tahapan dalam melakukan pengiriman barang dilakukan Perum BULOG diawali dengan suatu bagian membuat surat usulan yang dilakukan oleh Perum BULOG Divre NTB yang berisi permintaan order untuk kebutuhan barang untuk seluruh Divre se-NTB. Kemudian Perum BULOG menerbitkan surat permintaan barang kepada PT. Jasa Prima Logisittik serta daftar perincian harga perhitungan sendiri. Perum BULOG membuat kesepatan kontrak berupa Surat Perjanjian Kontrak. (SPK). Melalui kesepakatan tersebut PT. Jasa Prima Logisitik membuat Surat Jalan atau Delivery Order (DO) disertai dengan Surat Perintah Pengeluaran Barang (SPPB) setelah itu mengirimkan barang yang dipesan kepada Divre Jatim.

Sedangkan Alur penerimaan barang dari Perum BULOG ke Divre NTB lebih ringkas dan cenderung tidak memiliki prosedur yang rinci dibanding dengan pengiriman barang oleh PT. Jasa Prima Logisitik. freight forwarding yang dilakukan PT. Jasa Prima Logisitik dapat menggunakan jalur darat, laut, dan udara untuk darat dikirm secara langsung melalui truk barang tidak seperti laut atau udara menggunakan Bill of Landing dan Air Way Bill, setelah dikirim dan diterima oleh bagian pengurus barang gudang. Kemudian bagian gudang Perum BULOG Divre NTB membuat Berita Acara Serah Terima Barang (BAST). Setelah barang diterima Perum BULOG Divre NTB, PT. Jasa Prima Logistik dapat menagih pembayaran barang tersebut dengan Surat Tagihan berupa (SPP) yang sesuai dengan lampirab nomor (1) disertai dengan dokumen lain yaitu Faktur, Kwitansi, DO. SPPB, BAST. Berdasarkan keseluruhan penagihan tersebut, yaitu Surat Tagihan akan dipotong PPh 23 atas nilai bruto kecuali yang sudah dikenakan PPh 21. 
Gambar 4.4 Flowchart Permintaan dan penawaran

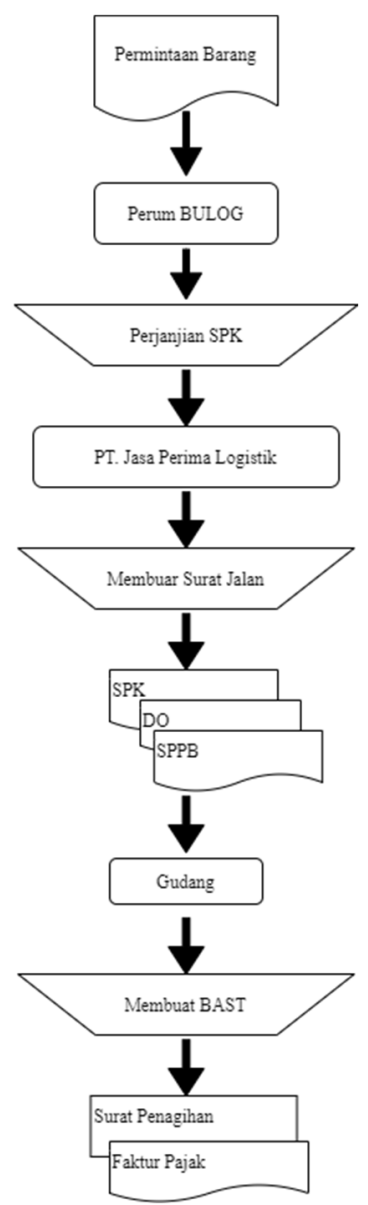

\section{Perhitungan Besaran PPh Pasal 23 atas Jasa Freight Forwarding}

Bagaimana mengetahui besarnya PPh Pasal 23 adalah dimulai dari pengiriman beras yang dilakukan oleh Perum BULOG yang menggunakan jasa PT. Jasa Prima Logistik untuk pengangkutan nya. Setelah barang dikirim ke tempat tujuan nya PT. Jasa Prima Logisitik memberikan Surat Tagihan atau Invoice ditempat tujuan nya yang nantinya dari Invoice tersebut nilai seluruh nominal tagihan dikenakan PPh 23 atau bisa berdasarkan nominal nilai kontrak didalam (SPK) sesuai dengan DPP Faktur Pajak dikenakan PPh 23 yang merupakan objek pajak berhubungan dengan jasa lain. Untuk Pajak Penghasilan Pasal 23 tidak ada batasan minimal tidak kena pajak PPh 23. Semua dikenakan atas berapapun nilai transaksi.Perum BULOG Divre NTB kepada PT. Jasa Prima Logistik dengan nilai Invoice diketahui bahwa di dalam biaya jasa terdapat Pajak Pertambahan Nilai yang harus dikeluarkan terlebih dahulu untuk dapat menghitung besarnya Pajak Penghasilan pasal 23. Tarif Pajak Pertambahan Nilai adalah sebesar $10 \%$ x biaya jasa, maka $10 \%$ tersebut harus dikeluarkan dengan rumus yaitu $100 / 110$ x biaya jasa. Sedangkan unuk Dasar Pengenaan Pajak (DPP) merupakan biaya jasa setelah dikuragi dengan Pajak Pertambahan Nilai (PPN).

Cara Perhitungan Pajak Penghasilan Pasal 23 atas Jasa Freight Forwarding:

1. Perhitungan pemungutan PPh Pasal 23 atas transaksi pengiriman beras komersil sebanyak $29.933 \mathrm{Kg}$ menggunakan pihak ketiga PT. Jasa Prima Logistik kepada Perum BULOG Divre NTB sesuai dengan lampiran Nomor (1).

Pada bulan Juli tahun 2020, Perum BULOG mendapat surat pengiriman Penyediaan Beras untuk stock Beras di NTB berdasarkan alokasi bulan Juli 2020, 
dengan permintaan sebanyak nilai kontrak . sehubungan dengan hal tersebut perhitungan DPP sebagai berikut:

Nilai kontrak $=5.687 .270 .00$ (Include PPN)

DPP $\quad=5.687 .270 .00 \times 100 / 110$

Jumlah Nilai Bruto

berdasarkan DPP

PPh 23 yang dipotong

$$
\begin{aligned}
& =\text { Rp } 5.170 .245 \\
& =\text { Jumlah Nilai Bruto } \times \text { Tarif Jasa } \\
& =\text { Rp5.170.245 x } 2 \% \\
& =\text { Rp } 103.405
\end{aligned}
$$

Maka total yang dibayarkan setelah dipotong PPh 23 berdasarkan perhitungan Perum BULOG Divre NTB sesuai perjanjian satu kontrak adalah 103.405 Tetapi dalam Masa Juli terdapat beberapa kontrak perjanjian (SPK). Sehingga pada pelaporan SPT Masa Juli terdapat penambahan nominal Jumlah Penghasilan Bruto dan PPh yang Dipotong.

Kasus diatas terdapat bukti contoh SPT Masa Juli PPh 23 atau 26, Bukti Potong PPh Pasal 23, SPP, Bukti Penerimaan Negara, Bukti Lapor SPT Masa Januari.

Atas transaksi tersebut PT. Jasa Prima Logisitk dipotong PPh Pasal 23, pemotong PPh Pasal 23 dilakukan oleh Perum BULOG Divre NTB dimulai dari terkirimnya barang ke bagian gudang kemudian dari pengiriman tersebut PT. Jasa Prima Logisitk sebagai pihak menyediakan jasa freight forwarding langsung dilakukan pemotongan PPh pasal 23 yang dihitung terlebih dahulu pada tanggal yang sama dengan tanggal penerimaan barang, lalu Perum BULOG Divre NTB menerbitkan Surat Setoran Pajak (SSP) yang berfungsi sebagai bukti potong PPh sebanyak 5 rangkap, yang mana rangkap pertama diserahkan kepada Perum BULOG yang sebagai pihak pemotong PPh pasal 23 dapat dilihat di lampiran , rangkap ketiga diserahkan kepada Kantor Pelayan Pajak (KPP) pada saat terjadi pelaporan Surat Pemberitahuan (SPT) masa PPh Pasal 23 dan SSP rangkap ke- lima disimpan oleh PT. Jasa Prima Logistik sebagai pihak yang dipotong PPh pasal 23 untuk diarsipkan. Selanjutnya pihak Perum BULOG Divre NTB menyetorkan PPh pasal 23 yang dipotong atas pengiriman barang dan disetor ke Bank Rakyat Indonesia (BRI) paling lambat tanggal 10 di bulan berikutnya setelah bulan pajak sebelumnya ketentuan ini telah sesuai dengan Peraturan Menteri Keuangan Republik Indonesia Nomor 242/PMK.03/2014 tentang Tata Cara Pembayaran dan Penyetoran. Berdasarkan kasus yang sudah diungkap sebelum memperlihatkan prosedur pemotongan penyetoran dan pelaporan bahwa kesesuain contoh kasus dengan pelaksaannya sudah sesuai.

\section{Prosedur Pemotongan Pajak Penghasilan Pasal 23 di Perum BULOG Divre NTB}

Menurut Peraturan Menteri Keuangan Nomor 244/PMK.03/2008 sebagaimana telah diubah dalam Peraturan Menteri Keuangan Nomor 141/PMK.03/2015, jasa keagenan yang termasuk dalam jasa freight forwarding temasuk dalam jenis jasa lain yang dipotong PPh pasal 23 dengan tarif sebesar $2 \%$ dari jumlah bruto tidak termasuk PPN. Demikian pula yang akan dilakukan oleh PT. Perum BULOG Divre NTB selaku pemotong PPh pasal 23, dan PT. Perum BULOG Divre NTB Mataram akan melakukan pemotongan PPh pasal 23 atas penghasilan yang diterima oleh PT. Jasa Prima Logistik yang bekerja sama dengan Perum BULOG Divre Nusa Tenggara Barat.

Perum BULOG Divre NTB Mataram melakukan pemotongan pada saat melakukan pembayaran setelah pihak rekanan mengajukan tagihan kepada PT. Perum BULOG Divre NTB Mataram dilengkapi beberapa dokumen pendukung, antara lain surat permohonan pembayaran yang mencantumkan nomor rekening rekanan, Kwitansi asli bermeterai, Faktur Pajak , fotocopy kartu NPWP rekanan dan dokumen pendukung lainnya Setelah surat permohonan pembayaran serta dokumen pendukung telah diterima oleh Perum BULOG Divre NTB Mataram, lalu dilakukan pengklasifikasian oleh bagian perpajakan, 
Kalau termasuk objek PPh pasal 23 makan akan dilakukan pemotongan atas penghasilan yang diterima PT. Jasa Prima Logisitik sesuai tarif yang berlaku.

Pemotongan PPh pasal 23, jumlah tagihan dari rekanan dikurangi dengan jumlah pajak, lalu selisih jumlah tagihan tersebut direkap untuk dilakukan pembayaran kepada rekanan melalui transfer bank sesuai dengan lampiran Nomor (2). Sebagai tanda bukti telah di lakukan pemotongan, Perum BULOG Divre NTB Mataram sebagai pemotong akan membuat bukti potong yang terdiri dari tiga rangkap, yaitu:

- Lembar ke 1 : untuk pihak yang dipotong PPh pasal 23

- Lembar ke 2 : untuk Kantor Pelayanan Pajak dilampirkan pada saat Pelaporan SPT Masa PPh pasal 23

- Lembar ke 3 : untuk Perum BULOG Divre NTB selaku pemotong

Bukti potong PPh adalah dokumen yang penting, baik bagi pihak pemotong atau pihak rekanan. Bagi pihak rekanan yang dipotong PPh, bukti potong PPh dapat digunakan untuk mengkreditkan pajak terutang atas penghasilan. Sedangkan bagi pihak pemotong, bukti potong PPh digunakan sebagai arsip untuk dokumen perusahaan. Pemotongan yang dilakukan Perum BULOG Divre NTB sudah cukup baik karena sudah sesuai dan langsung dilakukan pemotang jika data sudah lengkap.

\section{Gambar 4.5 Flowchart Pemotongan Pajak Penghasilan Pasal 23}

Prosedur Penyetoran Pajak Penghasilan PPh Pasal 23 di Perum BULOG Divre NTB

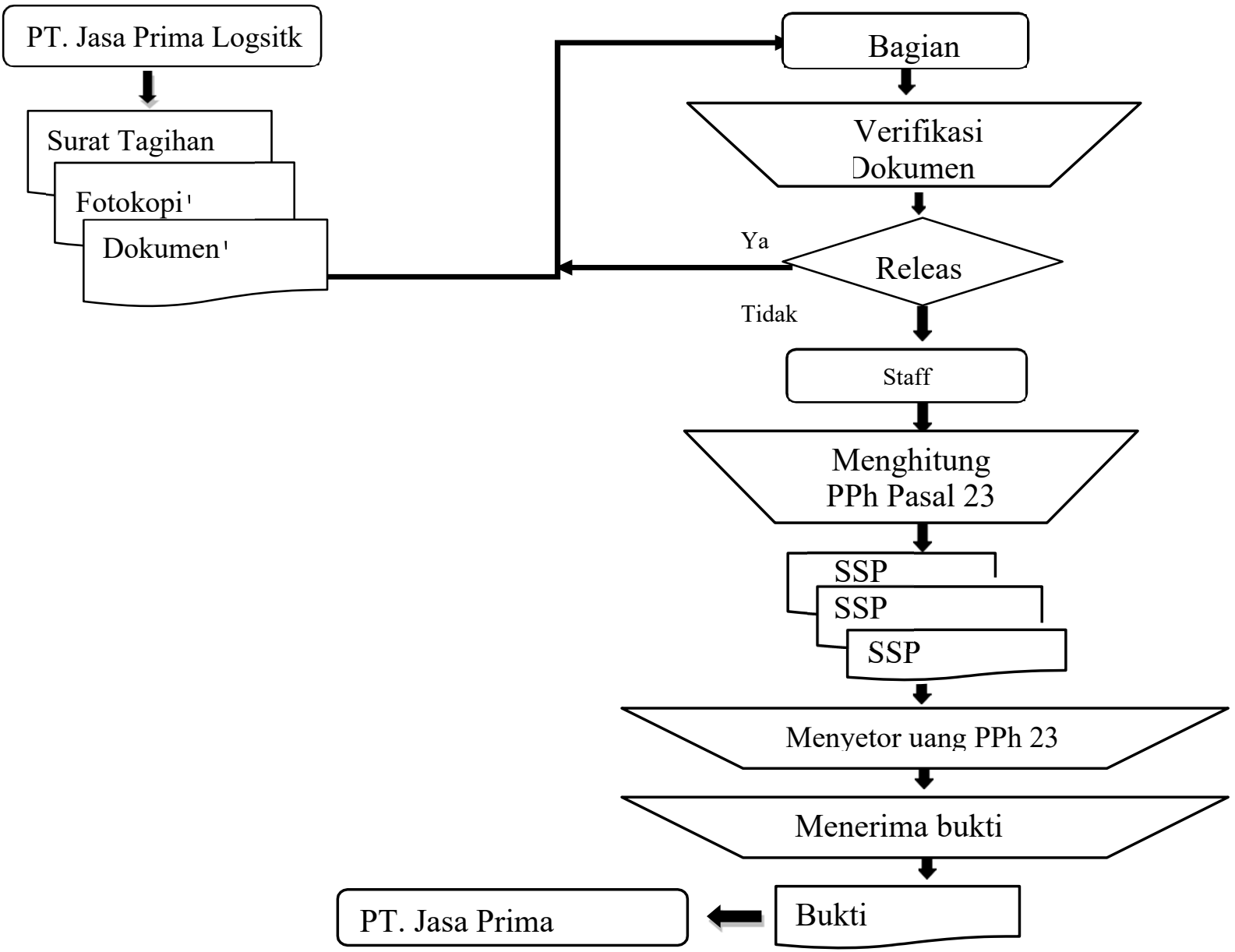

Sesuai dengan Peraturan Menteri Keuangan Republik Indonesia Nomor 242/PMK.03/2014 Tentang Tata Cara Pembayaran dan Penyetoran Pajak dan Peraturan Menteri Keuangan Republik Indonesia Nomor 80/PMK.03/2010 Tentang Perubahan Atas Peraturan Menteri Keuangan Republik Indonesia Nomor 184/PMK.03/2007 Tentang 
Penentuan Tanggal Jatuh Tempo Pembayaran atas pemotongan PPh Pasal 23 atas Perum BULOG Divre NTB dilakukan oleh perusahaan sebelum tanggal jatuh tempo atau pada saat jatuh tempo yaiu tanggal 10 setiap bulannya ke Kas Negara melalui bank persepsi yang dituju. Tanggal jatuh tempo pembayaran atau penyetoran pajak bertepatan dengan hari libur termasuk hari Sabtu atau hari libur nasional, pembayaran atau penyetoran pajak dapat dilakukan pada hari kerja berikutnya. Pengertian hari libur nasional termasuk hari yang diliburkan untuk penyelenggaraan Pemilihan Umum yang ditetapkan oleh Pemerintah dan cuti bersama secara nasional yang ditetapkan oleh Pemerintah. Berikut gambaran tentang penyetoran yang dilakukan Perum BULOG Divre NTB Mataram:

1. Bendaharawan mempersiapkan daftar bukti potong serta kode billing atas pajak yang dipotong, sesuai dengan lampiran Nomor (2 dan 3)

2. Kemudian pemegang buku bank perusahaan membuat checklist verifikasi untuk mencairkan dana yang akan digunakan untuk pembayaran PPh Pasal 23 atas persetujuan kepala bagian keuangan.

3. Lalu dibuatkan daftar transfer atau pembayaran melalui Bank persepsi (BRI)

4. Kemudian daftar transfer tersebut digunakan pemegang buku bank untuk membuat rekapitulasi data guna melakukan pembayaran ke Kas Negara melalui bank persepsi.

5. Setelah itu Perum BULOG Divre NTB menerima bukti setoran berupa SSP yang terdiri dari 5 (lima) lembar, yaitu:

a. Lembar ke-1 sebagai arsip Wajib Pajak sebagai pemotong (WP).

b. Lembar ke-2 untuk KPP melalui KPPN.

c. Lembar ke-3 dilaporkan Wajib Pajak (WP) ke KPP.

d. Lembar ke-4 untuk arsip Bank Persepsi atau Kantor Pos.

e. Lembar ke-5 untuk arsip Pemungut atau Pihak lain.

Penyetoran yang dilakukan Perum BULOG Divre NTB sudah cukup baik karena penyetoran sudah dilakukan sesuai prosedur yang berlaku sesuai dengan Peraturan Menteri Keuangan Republik Indonesia Nomor 242/PMK.03/2014 tentang di Tata Cara Pembayaran dan Penyetoran Pajak, serta mendapatkan bukti penerimaan negara yang sesuai dengan lampiran Nomor (4).

Gambar 4.6 Flowchart Penyetoran kepada Perum BULOG

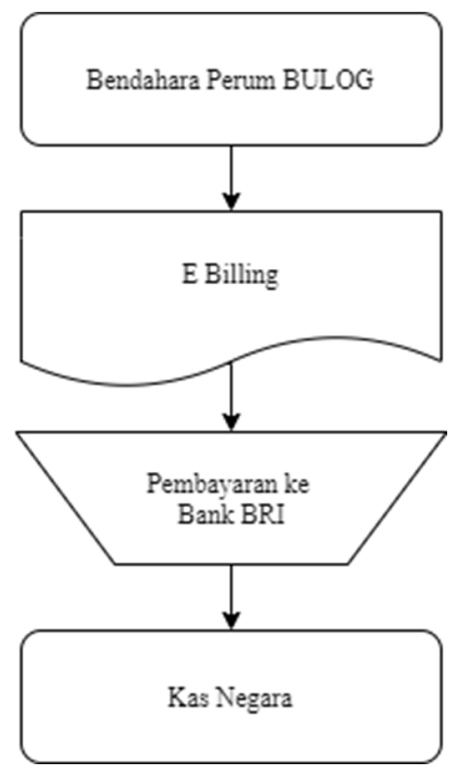




\section{Prosedur Pelaporan Pajak Penghasilan Pasal 23 di Perum BULOG Divre NTB}

Selaku pemotong PPh pasal 23 Perum BULOG Divre NTB Maataram juga berkewajiban melaksanakan pelaporan atas pemotongan PPh pasal 23 yang telah dilakukan pada PT. Jasa Prima Logisitik selaku jasa freight forwarding. Setelah pembayaran ke Bank Persepsi telah dilakukan, pihak Perum BULOG Divre NTB Mataram akan melakukan rekapitulasi data pajak untuk membuat dokumen pelaporan sesuai dengan lampiran Nomor (2 dan 5), yang berisi:

1. Surat Pemberitahuan (SPT) Masa PPh Pasal 23 atau 26,

2. Daftar Bukti Pemotongan PPh Pasal 23,

3. Bukti Pemotongan PPh Pasal 23,

Lalu melakukan pelaporan melalui situs DJP Online dengan E form selambatlambatnya tanggal 20 bulan berikutnya setelah Masa Pajak berakhir dan akan memperoleh Bukti Penerimaan Surat sebagai bukti telah melaporkan SPT.

Gambar 4.7 Flowchart Pelaporan oleh Perum BULOG

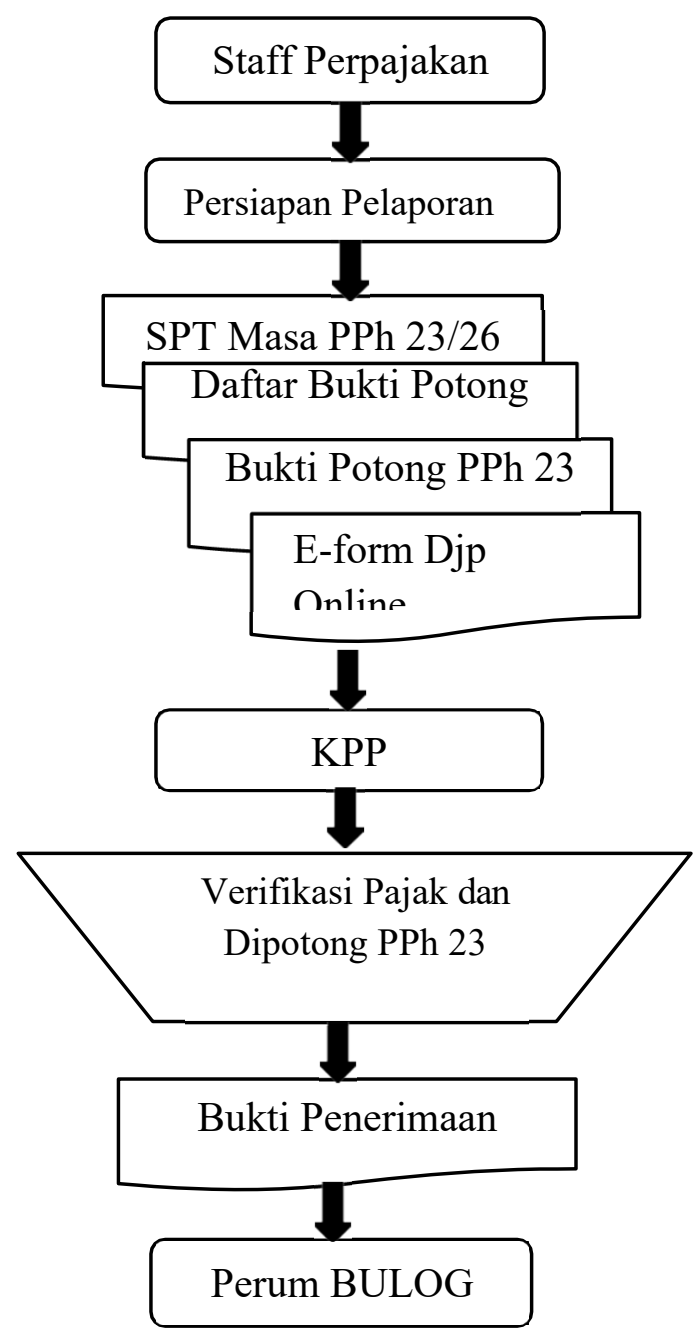




\section{Perbandinga Teori dan Praktik Penghitungan, Pemotongan, Penyetoran, dan Pelaporan PPh Pasal 23}

Tabel 1. Perbandingan Praktik dan Teori

\begin{tabular}{|c|c|c|c|}
\hline No & SECARA TEORI & SECARA PRAKTIK & KESESUAIAN \\
\hline 1. & $\begin{array}{l}\text { Penghitungan PPh Pasal } 23 \text { sesuai } \\
\text { dengan tarif yang berlaku sesuai } \\
\text { Pasal } 23 \text { ayat (4) Undang-Undang } \\
\text { Nomor } 36 \text { Tahun } 2008 \text { dengan } \\
\text { tarif } 2 \% \text { bila memiliki NPWP dan } \\
\text { jika tidak memiliki NPWP maka } \\
\text { akan dikenakan tarif } 100 \% \text { lebih } \\
\text { tinggi. }\end{array}$ & $\begin{array}{l}\text { Perhitungan PPh Pasal } 23 \text { pada } \\
\text { Perum BULOG Divre NTB Sudah } \\
\text { sesuai dengan aturan Undang- } \\
\text { Undang Yang di kenai tarif } \\
\text { sebesar } 2 \% \text { karna memiliki NPWP. } \\
\text { Dengan cara mengalikan nilai } \\
\text { kontrak yang sudah tidak } \\
\text { termasuk PPN dengan tarif yang } \\
\text { ada. }\end{array}$ & Sesuai \\
\hline 2. & $\begin{array}{l}\text { Pemotongan PPh Pasal } 23 \text { atas } \\
\text { Jasa Fright Forwading termasuk } \\
\text { dalam jasa keagenan yang sudah } \\
\text { di jelaskan pada Peraturan Mentri } \\
\text { Keuangan Nomor } \\
141 / \text { PMK.03/2015 termasuk } \\
\text { dalam jenis jasa lainnya yang } \\
\text { dipotong PPh pasal } 23 \text { sesuai } \\
\text { demgan tarif yang berlaku. }\end{array}$ & $\begin{array}{l}\text { Pemotongan dan pemgenaan tarif } \\
\text { PPh Pasal } 23 \text { atas jasa Freight } \\
\text { Forwarding pada Perum BULOG } \\
\text { divre NTB berlaandaskan atas } \\
\text { dasar Peraturan Mentri Keuangan } \\
\text { Nomor 141/PMK.03/2015 dengan } \\
\text { cara mengurani jumlah tagihan } \\
\text { dari renanan dengan jumlah } \\
\text { pajak, lalu selisih jumlah tagihan } \\
\text { tersebut direkap untuk dilakukan } \\
\text { pembayaran kepada rekanan } \\
\text { melalui transfer bank dan yang } \\
\text { terakhir dibuatkan bukti potong. }\end{array}$ & Sesuai \\
\hline 3. & $\begin{array}{l}\text { Perosedur Penyetoran PPh Pasal } \\
23 \text { atas jasa Fright Forwarding } \\
\text { yang sesuai dengan Peraaturan } \\
\text { Mentri Keuangan Republik } \\
\text { Indonesia Nomor } \\
\text { 242/PMK.03/2014 tentang } \\
\text { pembayaran dan penyetoran dan } \\
\text { Peraaturan Mentri Keuangan } \\
\text { Republik Indonesia Nomor } \\
80 / P M K .03 / 2010 \text { tetang penetuan } \\
\text { jatu tempo pembayaran atas } \\
\text { pemotongan PPh Pasal } 23 .\end{array}$ & $\begin{array}{l}\text { Perosedur penyetoran PPh Pasal } \\
23 \text { yang di lakukan Pada Perum } \\
\text { BULOG Divre NTB berlandaskan } \\
\text { atas dasar Peraturan Mentri } \\
\text { Keuangan Republik Indonesia, } \\
\text { dimana Penyetoran yang } \\
\text { dilakuakan oleh Perum BULOG } \\
\text { melalui Bank Persepsi yati Bank } \\
\text { BRI serta pembayaran di lakukan } \\
\text { pada jatuh tempo atau sebelum } \\
\text { jatuh tempo yaitu tanggal } 10 \\
\text { setiap bulannya ke kas Negara } \\
\text { menggunakan kode bayar melalui } \\
\text { E-billing. }\end{array}$ & Sesuai \\
\hline 4. & $\begin{array}{l}\text { Pelaporan PPh Pasal } 23 \text { atas jasa } \\
\text { Fright Forwarding yang sesuai } \\
\text { dengan Undang-Undang Nomor } \\
36 \text { Tahun } 2008 \text { dimana yang } \\
\text { melakukan pelaporan PPh pasal } \\
23 \text { adalah pemotong PPh pasal } \\
23 \text {. }\end{array}$ & $\begin{array}{l}\text { Perum BULOG selaku pemotong } \\
\text { PPh Pasal } 23 \text { atas jasa Freigh } \\
\text { Forwarding berkewajiban } \\
\text { melaporkan atas pemotongan PPh } \\
\text { pasal } 23 \text { yang telah } \\
\text { dilakukan,pelaporan PPh Passal } \\
23 \text { dilakukan oleh bendaharawan } \\
\text { BULOG melalui situs DJP Online } \\
\text { dengan E-form. }\end{array}$ & Sesuai \\
\hline
\end{tabular}




\section{SIMPULAN}

Berdasarkan pembahasan laporan ini, penulis dapat menarik beberapa kesimpulan yang berkaitan dengan penghitungan, pemotongan, penyetoran, dan pelaporan PPh Pasal 23 sebagai berikut:

1. Perhitungan besaran PPh Pasal 23 atas jasa Fright Forwarding pada BULOG sudah sesuai dengan tarif yang telah di ataur pada pasal 23 ayat (1) Undang-Undang Nomor.36 Tahun 2008.

2. Pelaksanaan Pemotonga PPh Pasal 23 atas jasa Freight Forwar pada Perum BULOG sudah sesuai Peraturan Mentri Keuangan Nomor 244/PMK.03/2008 sebagaimana yang telah diubah dalam Peraturan Mentri Keuangan 141/PMK.03/2015.

3. Prosedur penyetoran PPh Pasal 23 atas Jasa Freight Forwarding pada Perum BULOG sudah sesuai dengan Peraturan Mentri Keuangan Republik Indonesia Nomor 242/PMK.03/2014 tentang Tata Cara Pembayaran dan Penyetoran Pajak.

4. Prosedur Pelaporan PPh Pasal 23 atas Jasa Freight Forwarding pada Perum BULOG sudah sesuai dengan aturan yang ada, dan melaporkannya melalui situs DJP Online dengan E-Form.

\section{DAFTAR PUSTAKA}

A.Bahar Aulidya 2013,"Analisis pajak penghasilan pasal 23 atas jasa freight forwarding pada PT SILKARGO CABANG MAKASAR". Makasar. (Diakses pada 25 Februari 2021)

Anonim. 2021, Buku Pedoman Praktek Kerja Lapangan (PKL), 2021 Akademik D3 Perpajakan Fakultas Ekonomi Dan Bisnis Universitas Mataram (Diakses pada 23 Februari 2021)

Anonim.2019, "Perpajakan”https://www.cermati.com/artikel/pengertian-pajak-fungsidan-jenis-jenisnya (Diakses pada 23 Februari 2021)

Republik Indonesia 2008, Undang-Undang Nomor 36 Tahun 2008 Tanggal 23 September 2008 Tentang Perubahan Keempat Undang-Undang Nomor 7 Tahun 1983 Tentang Pajak Penghasilan.

Republik Indonesia 2015, Peraturan Mentri Keuangan Nomor 244/PMK.03/2008 yang sebagaimana telah diubah dalam Peraturan Mentri Keuangan Nomor 141/PMK.03/2015 tentang jenis jasa lainnya sebagaimana dimaksud dalam Pasal 23 ayat (1) hyruf $c$ angka 2 Undang-Undang nomor 7 tahun 1983 tentang pajak penghasilan sebagaimana telah beberapa kali di ubah terakhir dengan UndangUndang Nomor 36 Tahun 2008.

Republik Indonesia 2014, Peraturan Mentri Keuangan Nomor 242/PMK.03/2014 tentang tata cara pembayaran dan penyetoran paja 